\title{
NOTE
}

\section{Natroalunite on Ruapehu volcano, New Zealand}

\author{
I. J. GRAHAM and B. W. RoBInSON \\ Institute of Nuclear Sciences, DSIR, Lower Hutt, New Zealand
}

(Received March 6, 1986: Accepted August 12, 1986)

\begin{abstract}
A $5 \mathrm{~cm}$ diameter nodule recently recovered from the northern slopes of Mount Ruapehu, Taupo Volcanic Zone, New Zealand consists of bladed natroalunite, quartz and rutile. The natroalunite crystals are zoned, having $\mathrm{K}$-rich cores and $\mathrm{Na}$-rich rims, and are enriched in $\mathrm{Ba}$ and $\mathrm{Sr}$ over $\mathrm{Rb}$. The strontium isotopic composition (0.70535) is close to the average for Ruapehu lavas and the $\delta^{34} \mathrm{~S}(\% 0) \mathrm{CDT}$ value of +16.1 is similar to dissolved sulphate in Ruapehu crater lake. The nodule probably originated as a precipitate from hydrothermal fluids at low $\mathrm{pH}$, and was subsequently baked by hot lava.
\end{abstract}

\section{INTRODUCTION}

The precipitation of alunite from hot waters is commonly observed in geothermal and fumarolic areas of active volcanism around the world, e.g., Raymahashay (1968). In New Zealand, alunite minerals have been reported from the Wairakei geothermal area (Steiner, 1953) and the volcanoes: Mt. Egmont (Wood, 1971), White Island (Slansky, 1975) and Mt. Ruapehu crater lake (Giggenbach, 1974). The example described here (Victoria University catalogue No. 17426) is unusual because it was recovered as a small $(5 \mathrm{~cm}$ diameter) float-block nodule in the Whakapapanui stream bed, northern Ruapehu. Though of uncertain derivation it was most probably an inclusion in a recent Whakapapa Formation flow (W. R. Hackett, pers. comm. 1984). This note reports the chemistry and isotopic compositions of the nodule and its origin is discussed.

\section{Mineralogy, Chemistry AND IsOTOPIC COMPOSITION OF THE NODULE}

\section{Mineralogy}

The nodule is speckled orange-brown, is well-indurated and has a light-brown rind enclosing a fresh interior. Microscopic examination reveals a simple mineralogy of 0.1 to
$0.2 \mathrm{~mm}$ granular quartz grians $(45 \%)$, fibrous, sometimes radiating clots of natroalunite $(55 \%)$ and traces of rutile (Fig. 1). Individual natroalunite crystals are less than $0.5 \mathrm{~mm}$ wide and only a few microns thick. XRD analysis of the bulk-rock confirmed this mineralogy (see Table 1); all but two minor, high-angle peaks were assigned to either natroalunite, quartz or rutile and these are considered to be previously unreported peaks belonging to natroalunite.

\section{Chemistry}

Bulk rock chemistry is shown in Table 2; analytical methods used are those given in Graham (1985a). The sulphur content of the bulk rock was determined as $8.8 \%$ by $\mathrm{HF} /$ $\mathrm{HNO}_{3} / \mathrm{H}_{3} \mathrm{BO}_{3}$ digestion and precipitation/weighing of the sulphate as $\mathrm{BaSO}_{4}$. Low concentrations of $\mathrm{Fe}_{2} \mathrm{O}_{3}, \mathrm{MnO}, \mathrm{MgO}$ and $\mathrm{CaO}$ result from quartz, natroalunite and rutile containing only trace amounts of these elements. In the bulk nodule the only trace elements attributable to the natroalunite phase at concentrations $\geqslant 10$ $\mathrm{mg} / \mathrm{kg}$ are : $\mathrm{Ba}(114 \mathrm{mg} / \mathrm{kg}), \mathrm{Sr}(134 \mathrm{mg} / \mathrm{kg})$ and $\mathrm{Rb}(10 \mathrm{mg} / \mathrm{kg})$.

Ignition losses confirm the DTA patterns reported previously for natroalunite (Kashkai and Babaev, 1969) and indicate dewatering at $400-500^{\circ} \mathrm{C}$ and partial thermal decomposition $(2 / 3 \mathrm{~S}$ loss $)$ at $700-900^{\circ} \mathrm{C}$. EPMA analysis of 
the natroalunite crystals was extremely difficult owing to their high water content and thinness. Nevertheless, a partial analysis (Table 2) is similar to that derived after recalculating the bulk-rock analysis by removing from it $\mathrm{SiO}_{2}$ (quartz) and $\mathrm{TiO}_{2}$ (rutile). Individual natroalunite crystals are zoned (Fig. 1) with an increase in $\mathrm{Na}$ in the rims but constant $\mathrm{S}$ and $\mathrm{Al}$ contents.

\section{Isotopic Composition}

The whole rock ${ }^{87} \mathrm{Sr} /{ }^{86} \mathrm{Sr}$ ratio of the nodule is $0.70535 \pm 0.00005$ and the $\mathrm{Sr}$ is assumed to be present only in natroalunite. Natroalunite was leached from the nodule and the dissolved sulphate precipitated as $\mathrm{BaSO}_{4}$ for sulphur isotopic analysis. Its $\delta^{34} \mathrm{~S}_{\mathrm{CDT}}$ value is $+16.1 \pm$ $0.2 \%$.

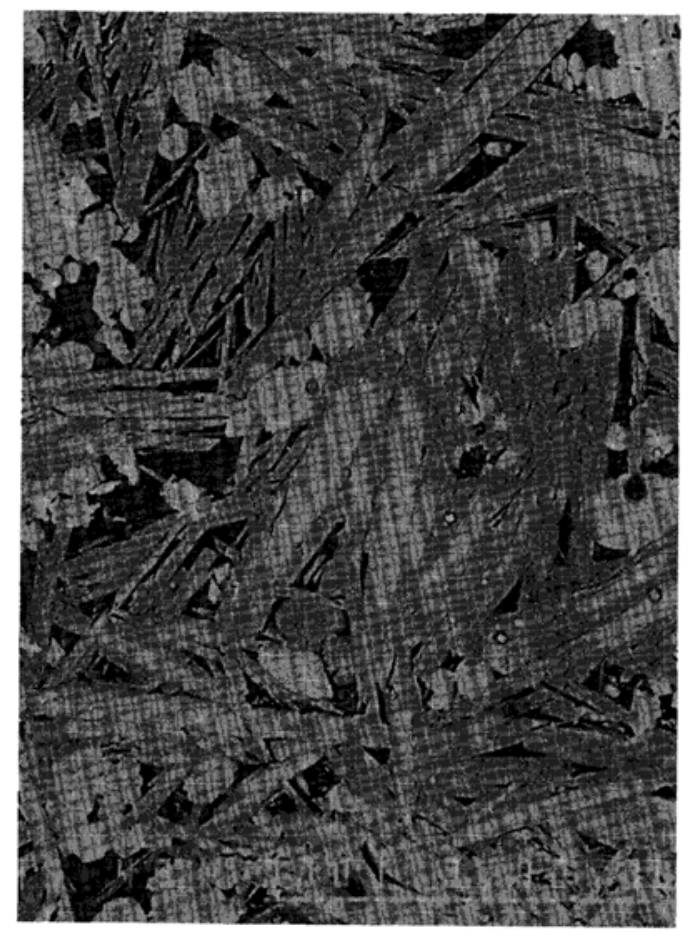

Fig. 1. Back-scatter Electron Image photograph of natroalunite-bearing nodule VUW 17426. Natroalunite blades are zoned with $\mathrm{Na}_{0.57}$ cores (lighter) and $\mathrm{Na}_{0.75}$ rims (darker). Other minerals are quartz (light-grey) and rutile (white). Scale bar (bottom right) $=0.1 \mathrm{~mm}$ $(100 \mu \mathrm{m})$.
Table 1.X-ray powder diffraction data of natroalunite in VUW 17426, compared to data published by Slansky (1975) (WI-4) and Parker (1962)

\begin{tabular}{crcrcr}
\hline \multicolumn{2}{c}{17426} & \multicolumn{2}{c}{ WI-4 } & \multicolumn{2}{c}{ Parker } \\
$\mathrm{dA}$ & \multicolumn{1}{c}{$\mathrm{I}$} & \multicolumn{1}{c}{$\mathrm{dA}$} & $\mathrm{I}$ \\
\hline 5.693 & 25 & 5.688 & 17 & 5.69 & 12 \\
5.610 & 14 & - & - & 5.58 & 12 \\
4.918 & $>100$ & 4.905 & 64 & 4.90 & 75 \\
3.490 & 50 & 3.488 & 32 & 3.49 & 24 \\
2.966 & $>100$ & 2.973 & 100 & 2.97 & 70 \\
2.965 & $>100$ & 2.966 & 89 & 2.96 & 100 \\
2.789 & 14 & - & - & 2.79 & 18 \\
2.222 & 41 & 2.224 & 11 & 2.221 & 50 \\
2.203 & 16 & 2.208 & 6 & 2.202 & 12 \\
1.894 & 54 & 1.896 & 22 & 1.894 & 30 \\
1.858 & 8 & - & - & 1.857 & 10 \\
1.741 & 39 & 1.744 & 17 & 1.744 & 22 \\
1.641 & 9 & 1.644 & 2 & 1.643 & 6 \\
1.500 & 7 & 1.501 & 2 & 1.501 & 6 \\
1.463 & 17 & - & - & 1.463 & 12 \\
1.316 & 5 & - & - & - & - \\
1.282 & 13 & - & - & - & - \\
\hline
\end{tabular}

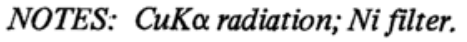

\section{Discussion}

Slansky (1975) reported an occurrence of natroalunite on White Island volcano: sample WI-4 appeared as a chalky-white, fine grained fragment with petrographic features similar to altered andesitic lava. Similarly, Raymahashay (1968) described the alteration of rhyolites by acid-sulphate springs to an assemblage of kaolinite, alunite and silica minerals, a process which has been demonstrated experimentally (Höller, 1967). For the Mt. Ruapehu volcano, Giggenbach (1974) described the suspended sediment material in the crater lake as consisting of amorphous silica, cristobalite, sodic alunite, gypsum and unaltered andesitic particles.

The composition of the alunite analysed by Giggenbach (1974) is $\mathrm{Na}_{0.56} \mathrm{~K}_{0.44}$ which corresponds to that expected for waters with a Na/ $\mathrm{K}$ atomic ratio of 15 to 20 (Parker, 1962; Zotov, 1971). Considering the exchange reaction:

$$
\begin{aligned}
\mathrm{KAl}_{3}\left(\mathrm{SO}_{4}\right)_{2}(\mathrm{OH})_{6}+\mathrm{Na}^{+} \\
=\mathrm{NaAl}_{3}\left(\mathrm{SO}_{4}\right)_{2}(\mathrm{OH})_{6}+\mathrm{K}^{+}
\end{aligned}
$$

Hladky and Slansky (1981) show that $\log a_{\mathrm{K}}+$ $/ a_{\mathrm{Na}^{+}}=-5.14$ at $25^{\circ} \mathrm{C}$ (hence alunite forms 
Table 2. Chemistry of natroalunite-bearing nodule 17426

\begin{tabular}{lcccrc}
\hline & Bulk rock & Na-alunite $1^{*}$ & Na-alunite $2^{*}$ & Rutile & $\begin{array}{r}\text { Recalculated } \\
\text { Na-alunite** }\end{array}$ \\
\hline $\mathrm{SiO}_{2}$ & 44.09 & 0.00 & 0.00 & 0.59 & 0.00 \\
$\mathrm{TiO}_{2}$ & 0.44 & 0.00 & 0.00 & 95.09 & 0.00 \\
$\mathrm{Al}_{2} \mathrm{O}_{3}$ & 20.99 & 36.70 & 37.31 & 0.30 & 38.09 \\
$\mathrm{FeO}$ & 0.21 & 0.00 & 0.00 & 3.21 & 0.00 \\
$\mathrm{MnO}$ & 0.00 & 0.00 & 0.00 & 0.00 & 0.00 \\
$\mathrm{MgO}$ & 0.02 & 0.00 & 0.00 & 0.00 & 0.00 \\
$\mathrm{CaO}$ & 0.09 & 0.00 & 0.00 & 0.00 & 0.00 \\
$\mathrm{Na}_{2} \mathrm{O}$ & 2.98 & 4.70 & 6.02 & 0.00 & 5.41 \\
$\mathrm{~K}_{2} \mathrm{O}$ & 1.52 & 4.80 & 2.66 & 0.00 & 2.76 \\
$\mathrm{P}_{2} \mathrm{O}_{5}$ & 0.04 & 0.00 & 0.00 & 0.00 & 0.00 \\
$\mathrm{Cr}_{2} \mathrm{O}_{3}$ & 0.02 & 0.00 & 0.00 & 0.88 & 0.00 \\
$\mathrm{SO}_{3}$ & $26.29 * * *$ & 37.40 & 37.40 & 0.00 & 39.95 \\
$\mathrm{H}_{2} \mathrm{O}$ & & - & - & 0.00 & 13.79 \\
$\mathrm{Total}$ & 96.69 & 83.59 & 83.39 & 100.07 & 100.00 \\
\hline
\end{tabular}

* EPMA analyses of natroalunite core (Na-alunite 1) and rim (Na-alunite 2) with beam width of $10 \mu m$ and reduced current. These analyses do not include water.

** Natroalunite recalculated assuming only $\mathrm{Al}, \mathrm{Na}, \mathrm{K}, \mathrm{S}$ and water included.

*** Loss on ignition at $1,000^{\circ} \mathrm{C}$ represents total combined $\mathrm{H}_{2} \mathrm{O}$ and $2 / 3$ equivalent $\mathrm{SO}_{3}$.

under most normal conditions) but the minerals can theoretically coexist for $\mathrm{pH}<4$. Zotov (1971) analysed alunites and coexisting thermal waters (up to $82^{\circ} \mathrm{C}$ ) and concluded that, for weakly mineralised, moderately acid solutions, the equilibrium for reaction (1) lies towards enrichment in $\mathrm{K}$ for alunites formed at higher temperatures. However, in more concentrated solutions the mineral composition will depend not only on temperature but on $\mathrm{pH}$ and Zotov (1971) found that in the Ebeko volcanic springs with $\mathrm{pH} 0.5$ and mineralisation up to $20 \mathrm{~g} / \mathrm{kg}$ Na-alunite forms. Similarly for the Ruapehu crater lake with mineralisation $28 \mathrm{~g} / \mathrm{kg}$ and $\mathrm{pH}$ 1.3 natroalunite would be expected and the natroalunite in the nodule has $\mathrm{Na}_{0.57-0.75}$. The mineral is thought to have been formed from a solution whose dissolved constituents were leached from andesitic magma.

The average Ruapehu andesite contains : $3 \% \mathrm{Na}, 1.5 \% \mathrm{~K}, 250 \mathrm{mg} / \mathrm{kg} \mathrm{Sr}, 350 \mathrm{mg} / \mathrm{kg} \mathrm{Ba}$ and $50 \mathrm{mg} / \mathrm{kg} \mathrm{Rb}$. Crater lake waters contain $800-1,500 \mathrm{mg} / \mathrm{kg} \mathrm{Na}, 80-200 \mathrm{mg} / \mathrm{kg} \mathrm{K}, 1-3 \mathrm{mg} /$ $\mathrm{kg} \mathrm{Sr}$ and 0.4-2.2 mg/kg Rb (Giggenbach, 1974). Significant amounts of $\mathrm{Sr}(134 \mathrm{mg} / \mathrm{kg})$ and $\mathrm{Ba}$ $(114 \mathrm{mg} / \mathrm{kg}$ ) enter the natroalunite (and probably also gypsum). The $\mathrm{K}-\mathrm{Na}$ site in alunite has 12 fold co-ordination and is relatively tolerant to ionic size. $\mathrm{Sr}$ and $\mathrm{Ba}$ are reasonably close to $\mathrm{K}$ and $\mathrm{Na}$ in size and are, in addition, doubly charged. However, $\mathrm{Rb}$ with a significantly larger ionic radius and only a single charge is not admitted to the structure and concentrates in the solution.

The zonation of the alunite crystals as shown in Fig. 1 with $\mathrm{Na}$ richer rims must be explained. Giggenbach (1974) reported a detailed study of the Mt. Ruapehu Crater Lake chemistry covering before, during, and after an eruptive period in 1971. The lake water is saturated or supersaturated with many constituents derived from the interaction of acid waters with andesitic magma. Increases in the concentration of elements such as $\mathrm{Na}$ (which are not limited by solubility) were noted during the eruptive period and during quiet periods the concentration decreases owing to dilution by meteoric and fumarolic water. The concentrations of sulphate, $\mathrm{Ca}, \mathrm{Al}, \mathrm{K}$ (and to a small extent $\mathrm{Na}$ ) are controlled by the precipitation of gypsum and alunite in response to variations in the sulphate concentrations as a result of changes in $\mathrm{pH}$, according to:

$$
\mathrm{HSO}_{4}^{-}=\mathrm{SO}_{4}^{2-}+\mathrm{H}^{+}
$$

During an eruptive period acid gases are absorbed by the lake water and remain in solu- 
tion but Giggenbach (1974) shows that these acids are partly neutralised by the oxidic constituents of the magma so that the $\mathrm{pH}$ of the lake water increases during such a period (from 1.2 to 1.8 ) and then drops again to 1.2. Over the same period the sulphate concentration dropped from about $10,900 \mathrm{mg} / \mathrm{kg}$ to $500 \mathrm{mg} /$ $\mathrm{kg}$ then rose to $16,800 \mathrm{mg} / \mathrm{kg}$. Similarly $\mathrm{Na}$ and $\mathrm{K}$ rose from 750 and $80 \mathrm{mg} / \mathrm{kg}$ to 1,500 and $100 \mathrm{mg} / \mathrm{kg}$ respectively, thereafter $\mathrm{Na}$ decreased to $1,100 \mathrm{mg} / \mathrm{kg}$ and $\mathrm{K}$ increased to $200 \mathrm{mg} / \mathrm{kg}$ (Giggenbach, 1974). The drop in sulphate represents the precipitation of gypsum and alunite but the later steady increase in sulphate and $\mathrm{K}$ result from the redissolution of these minerals as a function of the decrease in $\mathrm{pH}$. Lake sediment samples analysed by Giggenbach (1974) show an enrichment of $\mathrm{Na}$ during the eruptive period and could account for the natroalunite crystal-cores with $\mathrm{Na}_{\mathbf{0 . 5 7}}$. The natroalunite crystal-rims with $\mathrm{Na}_{0,75}$ presumably formed during an even more active period in the lake when the $\mathrm{Na} / \mathrm{K}$ ratio in the water was higher. The zoning then represents two active periods in the lake, the last one being more active with a probable dissolution period in between.

Dissolved sulphate in the crater lake has been analysed for its sulphur isotopic composition since 1968. The average $\delta^{34} \mathrm{~S}_{\mathrm{CDT}}$ is +17.8 $\pm 1.1 \%$ o $(n=12)$. Elemental sulphur in the lake has a $\delta^{34} \mathrm{~S}$ value of about $-7.9 \%$ and a sample of gypsum a value of $+13.5 \%$. Sulphate forms in the lake by oxidation of $\mathrm{H}_{2} \mathrm{~S}$ and $\mathrm{SO}_{2}$ gas. Isotopic fractionation between this sulphate and the reduced sulphur will take place because of the low $\mathrm{pH}$ and high $\mathrm{SO}_{4}$ concentration $(\sim 10,600$ $\mathrm{mg} / \mathrm{kg}$ ), although equilibrium values have not been reached. The $\delta^{34} \mathrm{~S}$ value for the natroalunite nodule $(+16.1 \%$ ) links it to the crater lake or similar environment at a time when the dissolved sulphate had a slightly lower $\delta^{34} \mathrm{~S}$ value. The measured $\mathrm{Sr}$ isotopic composition of the natroalunite (nodule) is close to the average of 101 analyses of Ruapehu lava: ${ }^{87} \mathrm{Sr} /$ ${ }^{86} \mathrm{Sr}=0.70531 \pm 0.00062 \quad(2 \sigma)$ (Graham, 1985b).
Natroalunite, quartz, and rutile were precipitated in hydrothermal waters emanating from Mt. Ruapehu or in the crater lake. This explains best the simple mineralogy and bulk rock chemistry of the nodule. The indurated nature of the inclusion resulted from the thermal effect of contact with hot lava during eruption but the nodule could not have been a xenolith as such, since combined water would have been lost from the natroalunite at temperatures above $400^{\circ} \mathrm{C}$. It is surprising that rutile and not anatase (the $\mathrm{TiO}_{2}$ polymorph normally found in the hydrothermal environment) is formed. Since it is not known from the lavas of Mt. Ruapehu, it can not be a residual mineral from andesite decomposition.

Acknowledgements-The authors wish to thank Drs. W. F. Giggenbach and R. Krupp for comments on the manuscript.

\section{REFERENCES}

Giggenbach, W. F. (1974) The chemistry of Crater Lake, Mt. Ruapehu (New Zealand) during and after the 1971 active period. N. Z. J. Sci. 17, 33-45.

Graham, I. J. (1985a) Rb-Sr geochronology and geochemistry of Torlesse metasediments from the Central North Island, New Zealand. Chem. Geol. (Isotope Geoscience Sect.) 52, 317-331.

Graham, I. J. (1985b) Petrochemical and Sr isotopic studies of lavas and xenoliths from Tongariro Volcanic Centre - Implications for crustal contamination of calc-alkaline lavas. Unpub. Ph. D. thesis, Victoria University, Wellington, N.Z.

Hladky, G. and Slansky, E. (1981) Stability of alunite minerals in aqueous solution at normal temperature and pressure. Bull. Mineral. 104, 468-477.

Höller, H.(1967) Experimentelle Bildung von AlunitJarosit durch die Einwirkung von Schwefelsäure auf Mineralien und Gesteine. Contrib. Mineral. Petrol. 15, 309--329.

Kashkai, M. A. and Babaev, I. A. (1969) Thermal investigations on alunite and its mixtures with quartz and dickite. Min. Mag. 37, 129-134.

Parker, R. L. (1962) Isomorphous substitution in natural and synthetic alunite. Am. Mineral. 47, 127136.

Raymahashay, B. C. (1968) A geochemical study of rock alteration by hot springs in the Paint Pot Hill 
area, Yellowstone Park. Geochim. Cosmochim. Acta 32, 499-522.

Slansky, E. (1975) Natroalunite and alunite from White Island volcano, Bay of Plenty, New Zeland. N. Z. J. Geol. Geophys. 18, 285-293.

Steiner, A. (1953) Hydrothermal rock alteration at Wairakei, New Zealand. Econ. Geol. 48, 1-13.
Wood, C. P. (1971) Analysis of white powder found on Egmont summit collected by D. H. Rawson. Unpub. rept. N. Z. Geol. Surv. Lower Hutt.

Zotov, A. V. (1971) Dependence of the composition of alunite on the temperature of its formation. Geochem. Internat. 8, 71-75. 